Dr. BALY, in the abstract, had referred tuberculous scrofula to imprisonment. He considered this disease to consist of a deposit of tubereulous matter in the lymphatic glands, the serous membranes, or any organ of the body.

Mr. Bossy, in reference to the inquiry of Mr. B. Cooper, remarked, that Dr. Baly had correctly described the scrofula developed by imprisonment as tubercular eachexy. It shewed itself by paleness, weakness, and general debility of the frame; and these were so marked, that he (Mr. B.) could, in examining a number of men, easily determine which of them had been subjected to imprisonment. Dr. Webster had remarked, that short imprisonment appeared to have a beneficial influence upon health, and this was apparently the case, for from want of exercise, and the use of fluid diet, there would be an increase of fat. He had found, however, that the improvement in health was not real, for, upon putting these persons to labour, they were incapable of muscular exertion. There was, moreover, a loss of weight in them. These were the persons in whom, if imprisonment were continued, tubercular disease would develop itself. With respect to the prevalence of tubercular disease generally, the mortality from this cause in the hulks had been increased by a circumstance which should be mentioned. On the carrying of the Emancipation Act in 1834, the black convicts of the West Indies were sent to this country on their way to Van Dieman's Iand. They arrived chiefly in the autumnal season, and phthisis developed itself in great numbers as the effect of confinement and cold. This accounted for the large mortality for some time, from phthisis, in the hulks. The cruelty of this plan was represented to the Government, and was not persevered in. In addition to this, also, it might be stated, that pardon was not granted to prisoners in the hulks on account of ill health. He differed with Dr. Baly respecting the influence of prison food in the production of diarrhoa, and gave two or three illustrations in point. In one of these he traced the prevalence of this disease to soup containing a quantity of barley-husks; and, in another instance, to the bread used by the prisoners having been made of flour, a quantity of which had been ground from wheat damaged by the sea, and which had began to vegetate. In both these instances the bowel complaint prevailed during the time the prisoners were partaking of the unwholesome diet, and disappeared on substituting more healthy food. He agreed with Dr. Webster that hot air prodnced catarrh, and chronic bronchitis, if not phthisis. In the Chelmsford Prison, the prisoners were taken from a cell of high temperature to stand at the cold treadmill, and were again taken to the cell. Catarrh was frequently caused in consequence. This had also occurred in other prisons.

Dr. WeBster expressed his satisfaction that Mr. Bossy's extensive experience respecting prisoners coincided with the opinions he had expressed relative to the influence which particular kinds of food produced on the health of the inmates of prisons. In addition to the facts Mr. B. had stated, he (Dr. W.) might mention, that in Bridewell, although situated in a confined locality of the city of London, near Fleet-ditch and Puddle-dock, bowel complaints, or any serious disease, had not been prevalent, notwithstanding the prisoners were not allowed to take regular out-door exercise. Generally speaking, the men were employed on the treadmill, and the women in picking coire, but their food was of good quality, and the bread excellent; indeed, it could not be purer, as the corn was ground in the prison, and baked at the House of Occupations, with yeast also made on the premises. He (Dr. W.) was likewise gratified to hear that Mr. Bossy entertained similar opinions with himself respecting the ventilation of prisons, and the injurious influence which the breathing of hot dry air had in producing pectoral disease amongst the inmates. Having stated, in the previous remarks he (Dr. W.) had taken the liberty of offering to the Society, that a large proportion of the prisoners recently pardoned at the Penitentiary were discharged on account of being affected with phthisical symptoms, he would now ask Dr. Baly whether any of these patients had subsequently recovered; for if such were the case, the fact would shew that their residence in prison tended materially to produce consumption. With reference to the lunaties sent to Bethlehem Hospital from the Penitentiary, it must be satisfactory to Dr. B. to hear, that during last year, four individuals formerly under his care in that prison had been cured, and removed from the hospital by warrants of the Secretary of State.

Dr. BALY replied, that in a great number of cases of phthisis at the Penitentiary, apparently hopeless, the disease was immediately checked on the release of the prisoners, many of whom entirely recovered. A favourable change took place almost immediately they were informed of their probable change. These cases shewed, in a remarkable manner, the influence of mind on the progress of disease. Mr. Bossy had, in some degree, misunderstood him with reference to the causes of diarrhoea and dysentery, which he admitted might occasionally be produced by impure food. But when diarrhoea and dysentery were prevalent for several years, they did not then arise from diet, but were always dependent on the locality of the prison. The causes mentioned by Mr. Bossy as productive of bowel complaints could not be always prevalent. Faets which he (Dr. B. ) had referred to in his paper proved that his view was correct, for not only were these diseases found to be more prevalent at particular seasons, as in spring and autumn, but when they were epidemic in the surrounding neighbourhood. In these instances the diseases were owing to miasma.

Dr. GrEgonY suggested that as Dr. Baly was about to furnish other papers on the subject of disease in prisons to the Society, much benefit would be derived, particularly in respect to age, if he directed his attention to the acquirement of the tubercular diathesis in a number of persons under circumstances directly the reverse to those of prisoners. He thought soldiers offered this opposite condition. He had been struck with the origin of phthisis in the recruits of several regiments, particularly the foot guards. It was a curious fact, that many of these men, even though carefully examined by the stethoscope, and pronounced healthy, at the end of a few months fell victims to tubercular disease. The announcement of the result of investigation into these cases in Mr. Baly's paper would increase its value and enhance our knowledge of the subject.

Dr. Baly was obliged for the hint thrown out by Dr. Gregory. He was well acquainted with the prevalence of consumption among the foot guards, who suffered from this disease to twice the extent, as did the cavalry regiments. He did not agree with Dr. Gregory as to their being placed under circumstances the reverse of prisoners; on the contrary, they were subjected to several of the same injurious influences. Nothing, for instance, could be worse than the ventilation of the barracks, particularly those in Portman-street and in the Tower. There was no ventilation whatever in the rooms they slept in, and these their sitting-rooms also. They mounted guard frequently, and were therefore frequently exposed to cold, as were prisoners. There was another cause which also acted on both these classes, and this was, the listless state of mind which re* sulted from their condition, and the inactive state of their bodies, both having a tendency to the production of tubercular disease. To these might be added, perhaps, their dissolute habits.

Mr. Cooper regarded the depressed condition of mind of the recruits, conjcined with their severe exercise in drilling, as a further cause of phthisis in these men.

Mr. Propert considered that the well-known indulgence of recruits-who were generally fresh from agricultural pursuitsin drinking, and their contraction of venereal disease, must have an influence in the destruction of their health.

Mr. Macrlwain considered Dr. Baly's paper important in reference to the causation of disease and its amelioration. He inquired whether in those prisons in which diarrhœa was prevalent, as the result of locality, the peculiarity was in the soil, or in the ordinary matters of drainage. He made some remarks on the influence of ventilation on the function of the lungs.

Dr. BArx regarded the diarrhoea as the effect, not of imperfeet drainage, but of a moist state of ground for some extent round the prison. The Wakefield Honse of Correction, in which diarrhœa was more generally prevalent than in any other prison of England, was situated in a hollow valley of clay, which was often flooded in winter, and in summer was not quite dry. The sub-soil was clayey, the surface of a rich vegetable character.

\section{THE MEDICAL PROTECTION ASSEMBLY.}

$$
\text { To the Editor of THE LANCET. }
$$

SrR,- - My attention has been drawn to a letter from Mr. Jerrard, of Honiton, published in this week's LANCET, respecting the expediency of the union of the two Metropolitan Associations into one body.

On the part of the Medical Protection Assembly I beg to remark, that this Association, in furtherance of the resolution adverted to by you in a note appended to the above letter, and anxious only for the establishment of those just and liberal principles lately published in your columns, and which they conceive are necessary to an equitable adjustment of the conflicting claims of their professional brethren, did apply, in a generous, candid, and honourable spirit, to the " Provisional Committee of the National Association," for the admission of four of the members of the Assembly to a seat in that committee, trusting that, by this means, a hearty co-operation might be secured, wise principles advocated, and the general good of the profession achieved.

This offer of co-operation was refused. The fact needs no comment. The limits of a letter do not permit me to enter into an 
exposure of conduat at once evasive, illiberal, and self-condemning. The men who were afraid to receive on their committee old and staunch reformers are not the men to claim the confidence of their professional brethren.

This short and unvarnished statement is necessary, in justification of the Medical Protection Assembly. The time is now come when that Assembly must republish its principles, re-assert its claims on professional support, and defeat the projects of a secret self-constituted tribunal, whose acts are conceived in darkness, and, when brought to light, are the very types of mental abortion and legislative deformity. I remain, Sir, yours truly,

Kennington, March 3rd, 1845.

\section{A METROPOLITAN MEDICAL PRACTICE. WITH REFLECTIONS. \\ To the Editor of THE LANCET.}

Srn,--I some time since saw a "Metropolitan Medical Practice" advertised, and, anxious to purchase a respectable introduction amongst a community such as London produces, I applied for information, and now send you the answer-a morceau too delicious to be lost.

Already is the medical profession so overcrowded, even in the face of an expensive education, that its natural jealousies, if I may use the expression, are increased a hundredfold, and men, otherwise, perhaps, strictly honourable, are obliged to descend, or, at all events, really $d o$ descend, to shifts and expedients, in order to obtain practice, which are highly derogatory. Competition amongst well-educated men, even for the poorest medical situation, has already gone to the utmost-to the most pitiable extent. And if such be the state of the profession now, when certain promises to act honourably are exacted from its members, and certain laws of etiquette exist to, in some degree, restrain their conduct, what would be its state were the flood-gates of empiricism to be opened upon us, - when the regular practitioner could be known from the charlatan only by the chance holding of a public appointment, and when all might legally set to work in tinkering that most complex, most ill-used, of all fabrics, the human constitution? The result in such case could be easily foreseen. Few high-minded men would like to enter a profession where the tares could scarcely be known from the wheat, and where the kibes of the courtier of medical science would be so closely pressed upon by the clogs of the quack.

I send my name and address in confidence. Do not publish the name of the party, but you are at liberty to shew the enclosed to any one who desires it. Print it verbatim et literatim.

Warwickshire, Feb, 16, 1845.

Yours, W. R. No. Srr,-In answer to your letter the House is situated at imp improving neighbourhood the House is newly Built containing 2 Kithens Shop \& Parlor first floor and I beleive a second floor a small Garden behind Rent including Taxes $£ 25$ per year as only been recently fitted up as a Druggists by $\mathrm{Mr} . \mathrm{T}^{* * * * * *}$, who holds a situation in the Home Missionary Society in Bloomfield St Finsbury Circus and they object to his continuing in the business he fitted it up without their Knowledge and would be glad to let it at a sacrafice that is to say for the value of the Shop fixtures Drugs \&ce. his son being to young to carry it on it will between $£ 140$ to $£ 150$ being no Medical man near I think it would be a most desireable opportunity being sure to meet with a good connection the Neighbourhood is very large indeed the business has been neglected as he could not give his time to it he his not a Medical man himself. I have been as explicit as possible. I remain yours most respectly ${ }^{\prime} *_{* * * * * * * *}$

" 8 , L- Street, City."

\section{THE COUNCILLORS OF THE COLLEGE OF}

\section{SURGEONS.}

IAETTER OF APOIOGY FROM MR. WILLIAM IAWRENCE TO IMR GEORGE JAMES GUTHRIE.

"To T. Wakley, Esq., M. P., \&c. \&c. \&c.

"SIR,-Having seen you as early as possible after my arrival in London, at the request of $\mathbf{M r}$. Guthrie, who considered that an unjust attack had been made on him in THE LANCET of the 25th Jan., and having had a long interview with you on that subject this morning, I have communicated the result to him-viz., That you acknowledged being the writer of the article, but disclaimed any intention of impugning Mr. Guthrie's personal or private character, at the same time reserving to yourself the right to criticize his conduct as a member of the Council of the College of
Surgeons, or that of any other public man. To such an editorial right, fairly exercised, no one can possibly object, more particularly when, as you informed me, the columns of your paper were open to any one who considered himself unjustly attacked or aggrieved. I shall therefore again repeat what I told you Mr. Guthrie complained of in the article to which I have alluded viz., that you accused him of praying to be heard by counsel against the Charter, and of not informing the members of the College of what was going forward, while the mischief was being perpe. trated, but that after it was completed, and the means of prevention no longer existed, then did he sound the trumpet of alarm, \&c., and "allowed the catastrophe to precede the warning." Now although all this may be literally true, according to the opinion you entertain of what $\mathrm{Mr}$. Guthrie might, and, indeed, as you told me, you thought he ought to, have done long before the presentation of his petition, yet if you had taken the trouble to consider that petition, it was, I think, evident on the very face of it, that the mischief he contemplated had not been perpetrated; for not one single Fellow had been made according to the ample power given to the Council of the College in the $4 \mathrm{th}$ clause of the Charter, on the interpretation of which, and the manner it was proposed to be carried into effect, Mr. Guthrie differed with his colleagues, remonstrated with the secretary of state, and subsequently on these grounds petitioned Parliament against the Charter.

"Under such circumstances, I do not wonder that Mr. Gathrie considered himself unjustly dealt with in the article which appeared in The LANCET of the 25th ult. On that artisle, after our conversation this morning, it is not my intention or inclination to comment farther than that as you have chosen to accompany your editorial remarks on $\mathbf{M r}$. Guthrie's conduct with those of Mr. Lawrence made to you eighteen years ago, which you say you have selected as one of THE LANCET's unpublished 'Curiosities of Medical Literature,' you will, perhaps, along with this, publish a letter, very recently written by that gentleman, addressed to a friend of Mr. Guthrie, of which I enclose you a copy; and have the honour to be, Sir, your ohedient, humble servant,

"Berkeley Street, Berkeley Square, Feb. 26th, 1845." A. Bannerman.

\section{“ 'To R. Keate, Esq.}

" "MY DEAR SrR,-Mr. Guthrie wrote to me on Monday last, stating that observations reflecting on him, and represented to have been written by me, had appeared in THE LANCET, and requesting to know whether $I$ acknowledged them. Not having seen the publication, and supposing that the inquiry referred to some recent production, I had no hesitation in disclaiming all knowledge of it. Having since read it, I called on you to say that the article in question must have been written by myself, at least in part, though from the time that had since elapsed (eighteen years or more) I could hardly remember the circumstances, and could not undertake to say what portion was or was not of my. writing.

" 'I do not pretend to justify the production in any manner, and $I$ would not say a word to revive the recollection of misunderstandings, unfriendly feelings, and divisions in the profession, which have completely passed away, and every trace of which has long been removed from my mind. Looking back to the past with the altered views and opinions which experience, reflection, and mature judgment bring with them, I am now surprised and concerned beyond measure, that I could have been so far misled by reports and stories, no doubt exaggerated and misrepresented, as to have written in this manner of Mr. Guthrie with whom I was then hardly acquainted; and $I$ now request of you, as a common friend, to convey to him the unreserved expression of my deep regret that anything offensive to his feelings, as an author or a gentleman, should at any time have proceeded from my pen. Trusting that he will accept this as my apology, I remain, my dear Sir, yours very faithfully,

" ' Whitehall-place, Jan. 31, 1845.' " ' Wurliam Lawrence.'

$$
\text { (" "True copy, R. Keate." ") }
$$

\section{PARTICULAR CREPITUS IN THE LUNG.}

To the Editor of THE LANCET.

SIR,-Permit me to correct an error into which you have fallen, in the remarks you were kind enough to make on that part of my paper relating to the occurrence of "crepitus in the lung after the absorption of a pleuritic effusion." You state that the sound I have alluded to was pointed out by M. Damoiseau in the October number of the Archives Generales for 1843, to whom you are inclined to give the credit of the discovery; but any one may learn from a perusal of M. Damoiseau's essay, that he describes a friction sound generated in the pleura, whilst the sound of which $I$ have spoken is a crepitus produced in the lung, and totally unlike 